\title{
Seton and His Woodcraft Movement
}

\author{
Yu Zhang \& Zhilian Zheng \\ School of Foreign Languages, Qingdao University of Science and Technology \\ Qingdao 266061, China \\ E-mail: zhangyu_qust@163.com
}

\begin{abstract}
This paper briefly explains some aspects that spurred Seton to organize the Woodcraft Indians, an organization that stresses the conservation of nature and character-building by means of outdoor activities and states that Seton's admiration of Native American traditions and life style has a profound influence on Woodcraft Movement. From Seton's personal experiences, we can see that all his personal activities formed a solid foundation for his environmentally minded pursuits later in life. Woodcraft Movement is the legacy that the conservation pioneer Seton left to the humankind.
\end{abstract}

Keywords: Seton, Woodcraft Movement, Indians, Conservation, Nature, The young

\section{Introduction}

It is well known that the world-renowned naturalist Ernest Thompson Seton (1860-1946) wrote many famous animal stories, such as the Wild Animals I Have Known, Animal Heroes, and Lives of the Hunted, etc., which have encouraged and symbolized a hearty communion with nature and wild animals. But the Chinese readers little know that Seton was the founder of the Woodcraft Indians and the Boy Scout of America. Founded in April, 1902, the Woodcraft Movement, which is primarily an educational movement with outdoor activities, such as swimming, boating, camping, forestry, nature-study, scouting, photography, etc., was a "character-making movement with a blue sky method, for all ages and both sexes." The movement, which attaches great importance to the making of character, aims to cultivate the ideal figures of all-round development who are physically strong, happy in helping, equipped for emergencies, wise in the lore of the woods, courteous and self-controlled in dealing with people and affairs. In some sense, the movement is one that makes entertainment a medium of education, in which the form of recreation is applied to the character-building. Seton's admiration of Native American traditions and life style has a profound influence on the movement. This paper mainly discusses some aspects that fostered Seton in founding the organization Woodcraft Indians.

\section{Personal experiences}

Interestingly, Seton was not a born Canadian or American. He was born in England and then at the age of six immigrated to Canada with his family. Curiously enough, as a toddler, Seton should love nature so much that one of the ways his mother let him sit still was to tell him, "You are a tree. Trees do not move," and thus it is said that he would sit motionless for more than an hour. When he was very young, Ernest Thompson Seton liked exploring the forest on the edge of the town several miles away from his home. He liked listening to the wondrous songs of the birds and following the dim trails. He was so absorbed in the beautiful nature around him that he often forgot to eat his lunch. The only way to cure his pain from his father's whipping was to look for the treasures in the woods or dodge in the cabin he put up in the Don Valley by himself. When he was studying at the Collegiate, he wrote and acted out with his friends and younger brothers an Indian play, whose hero was a villain, who was triumphant over the Europeans settlers. The success of the play endowed Seton with gratification of his instincts and he wanted to do what he thought was right: to organize an Indian tribe among his playmates. Only after all the others did not agree with him on this, did he compromise with them to start a Robin Hood Band instead. In 1875, Seton was invited to spend his summer on Blackwell's farm; there he savored the rurality. He led the others on the farm in the ways of Indian life. There he built a dam, built his first tepee, made bows and arrows and did everything he could to reestablish ways of Indian life.

From his personal intercourses with the Indians, Seton realized that most of the Indian natives were good, courageous and friendly. So different from most of his contemporaries, Seton had a tender heart to the Indians. When he first hunted with a Cree named Chaska, "We took to each other from the beginning. There was an indefinable charm about this quiet, dignified manners — and I knew that he could teach me much about woodcraft," he wrote in his autobiography. And 
indeed he learned much woodcraft from the Indian.

In 1892, Seton was appointed as the naturalist of Manitoba Province. When he explored the Winnipeg prairie, to his great surprise and disappointment, he found that everything had changed because of the farmers' plough: the lakes, the Sandhills, the strictly prairie birds, the striped gopher the sharp-tailed grouse, the swallows from the barns and the grey wolf. To him, all the sweet and wild things were gone. He began to realize the disaster man's plough brought to the Manitoba prairie. He could not help being deeply concerned with the future of the prairie. He wanted to do something to establish reservations for Native Americans and parks for animals threatened by extinction. But the conscience to conserve nature at that time was only an impulse and ten years later could he put his dream into practice.

Another aspect that prompted him to form an organization to conserve nature was his connection with Charles A. Eastman, a Sioux Indian from Minnesota. The latter acted as Seton's most effective instructor who taught him the Indian way of life. In establishing his own tribe of boy Indians, Seton absorbed various fine tribal cultures, for he bore the motto in mind: "The best things of the best Indians."

From Seton's personal experiences, we can see that all these activities formed a solid foundation for Seton's environmentally minded pursuits later in life. Through his continual exposure to nature and wilderness in Canada, toward life and the society of his time, he developed a quite revolutionary attitude, namely, he laid significant emphasis on a return to more traditional Native American-based relationship of humans with their surroundings. To sum up, Seton's personal life did have great influence on him and he gradually came to the direction of conserving nature by means of the Woodcraft Indians.

\section{A successful educator of the young}

Seton was successful in guiding the youth toward the directions he planned. One example will suffice in this:

In 1901, he had a large house of his own built in Connecticut. But soon after he moved in, he found that the youngsters nearby cut gaps in his high fence and wrote and drew shocking things upon his gate. Every morning he had to paint over the obscenities inscribed there the night before. This repeated for many times. It dawn on Seton that those boys had played, fished and hunted in the region long before he fenced it. Before long, he found that the boys entered and invaded his premises, shooting animals in his park and wreaking damage wherever they could. Instead of prosecuting the youngsters and putting the leaders of them into prison, as some of his friends advised him to do, Seton invited the boys to his house and dined together, played games together and then before they went to bed, Seton lost no time to tell they interesting stories about nature and the good Woodcraft Indians, who regarded chivalry, courage and honour as the three main virtues to be practiced. From then on, all these boys became Seton's intimate friends all their lives.

Seton believed that "not one boy in a thousand is born bad. Boys have their badness thrust upon them. They are made bad by evil surroundings during the formative period between school and manhood; between twelve and twenty years of age." And he believed that if a boy was given "something to do, something to think about, and something to enjoy in the woods," it was possible to lead his energies into some achievements. It is because Seton instilled the Indian woodcraft lore to the young, they had "something to do, something to think about, and something to enjoy in the woods", that nearly all of them became useful persons to the country when grew up, some holding very important social positions.

In educating children, Seton was unusual at that time. Maybe he had suffered enough from his father's cruel home government. Seton did not want to adopt the same punishment to the boys who were naughty and mischievous. Yes, indeed, at that time, he had no children of his own. He did not have any experience working with the children. He did not even know how to get along with the young. But in his mind, he felt that he would lead the young toward a healthy way, toward the way that would lead to a new, harmonious relationship between man and nature.

In Seton's mind, the solution to the deterioration of America, the hope and future of America lay in America's young people. He saw that the industrial growth and the expansion of urban America were depriving the country and its youth of many of the fine qualities which should have great impact on their lives: "money grubbing, machine politics, degrading sports, cigarettes, town life of the worst kind, false ideals, moral laxity, and lessening church power, in a word, 'city rot' has worked evil in this nation."

Seton was anxiety-ridden in facing such an austere challenge at the period of transformation. His personal experience enabled him to realize that "those live longest who live nearest to the ground, that is, who live the simple life of primitive times, divested, however, of the evils that ignorance in those times begot." To Seton, the Indian living in harmony with his environment accorded with this ideal, and the Indian unit of organization was most probable to make the dream come true. Thus he wrote in The Gospel of the Redman:

"No man owns the wood of the forest, or the water of the rivers, or the soil of the earth. He did not make them, they are the harvest of the land that belongs to the whole people; and only so much of them is his as he can gather with his own hands and use in his own home....

The Tribe may give to one family the exclusive right to hunt or gather wood or forage or wild rice or fruit in one tract or range, but the family cannot sell this right, nor can they hire others to hunt or gather for them, lest the hunting be destroyed by overdrain. " (Seton, 1966, p26) 
By illustrating the Indian way of life, Seton depicted the mankind's ideal to live in harmony with its nature, so that in the future nature would also provide mankind with the necessities of life nonstop.

It must be said that another factor fostered him in his moving steadily in the direction of conserving and organizing the Woodcraft Indians: he was greatly influenced by James Mavor, a political economics professor at the University of Toronto, who had a strong propensity for Fabian Socialism. During the ten years prior to the founding of the Woodcraft Indians, they met frequently and discussed many times and Seton came to understand the ideas of socialism. It is apparent that his personal experiences, his exploration of the prairies, his connection with the economic professor, and his identification with the Indian and with wild creatures, all together molded his ideas of the Woodcraft Indians.

In describing the inspiration behind his organization of the Woodcraft Indians, he said, "It would help bring together young people from various so-called stations, break down the barriers that society has foolishly placed upon them, and establish in their minds when they are young a finer kind of humanity, a real understanding that the important thing is the association of a human spirit."

The Woodcraft movement proved to be a huge success with many members of the organization becoming upright and respectable citizens, and it soon caught the attention of newspapers and educators. One prominent educator even said to Seton: "What a monument such an organization would be to your life!"

A monument it is indeed to Seton's life and is of great consequence to the following generations. When it comes to the explanations, we must say that the reasons for his success are both complicated and varied. Admittedly, Seton's idea of the Woodcraft Movement emerged as the times required. Around the end of $19^{\text {th }}$ century, a change was taking place unawares in the American lifestyle. The public began to rediscover their roots in nature and Native American society rather than to regard the materialism of the pioneering age as the pursuit of their life. To some extent, the movement met the needs of the society. Seton was strongly convinced that what was best for American people to do was to interact with the land in a concordant relationship, conserving their resources and landscapes, and learning from the Native Americans who had once lived in American forests and prairies.

\section{Conclusion}

Woodcraft Movement is the legacy that the conservation pioneer Seton left to our humankind. In retrospect, we can better understand what we should do in order to live peacefully with nature; we can better understand the ways in which the environment is conserved. Inspired by Seton's example, more and more people, old and young, the world over, are open-minded in terms of how to interact with nature instead of regarding nature as merely a source of profits. Just as Seton concluded in The Gospel of the Red Man:

"Our system has broken down__ our system is a failure. Wherever pushed to logical conclusion, it makes one millionaire and a million paupers. There is no complete happiness under its blight and still I held my vision of the perfect man_ athletic, fearless, kind, picturesque, wise in the ways of the woods, and without reproach of life. And, by a long, long trail, with ample knowledge of histories and of persons, I was led, as many before have been, to choose the ideal Red man. By all the evidence at hand, his was a far better system, a better thought, because it produced far nobler, better men. He, more than any type I know, is the stuff that fires our highest dreams of manhood, realized complete. Him, therefore, I proclaim as the model for an outdoor life, our travel guide of the fourfold way that leads to perfect manhood." (Seton, 1966, p110)

Ernest Thompson Seton did not merely regarded the Indian way as ideal; on the contrary, he led the young to put the ideal into practice. Seton and his Woodcraft Indians were representatives of the public awareness of the significance of the preservation of the wilderness and natural resources. It is obvious that by participating in the movement, many boys transcended their previous relationship with their natural surroundings, holding a new reverence for natural beauty and nature's creatures. Since then, not only the young people, but also more and more adults are gradually interested in the outdoor organization and begin to realize that nature and environment concern everyone on the earth. Through the Woodcraft Movement, Seton inspired the conservationist attitude into the people of the early $20^{\text {th }}$ century and future generations.

\section{References}

Garst, Shannon and Warren. (1959). Ernest Thompson Seton-Naturalist. New York: Julian Messner, Inc.

Keller, Betty. (1998). Black Wolf: The life of Ernest Thompson Seton. Douglas \& Mcintyre.

Polk, James. (1972). Wilderness Writers, Clarke Irwin \& Company Limited.

Seton, Ernest Thompson \& Seton, Julia M. (1966). The Gospel of the Redman: A Way of Life. Santa Fe: Seton Village Press.

Seton, Ernest Thompson. (1978). Trail of an artist-naturalist: the autobiography of Ernest Thompson Seton. New York: Arno Press. 